\title{
Architecture as Frozen Music: Italy and Russia in the Context of Cultural Relations in the $18^{\text {th }}-19^{\text {th }}$ Centuries
}

\author{
By Tatiana Samsonova*
}

\begin{abstract}
This article deals with the two kinds of art, architecture and music, in their stylistic mutual influence on the historical background of St. Petersburg's founding and developing as the new capital of the Russian Empire in the early 18 ${ }^{\text {th }}$ century. The author highlights the importance of Italian architects and musicians in the formation of modern culture in Russia and shows how the main features of Baroque and Classicism are reflected both in the architecture and music thanks to the influence of the Italian masters. For the first time the issue of the "Russian bel canto" formation resulted from the Italian maestros working in Russia in 18-19 centuries is revealed.
\end{abstract}

Russian-Italian relations originated in the $18^{\text {th }}$ century and covered various cultural phenomena. Their impact is vividly seen in architecture and music in St. Petersburg, which was founded in 1703 by the Russian Emperor Peter the Great whose strong desire was to turn Russia into Europe. As the famous Russian poet Alexander Pushkin wrote in his "The Bronze Horseman" (1834), "the Emperor cut a Europe window." For St. Petersburg construction as a new Russian capital outstanding Italian architects were invited. The first Italian architect, who came to St. Petersburg, was Domenico Trezzini (16701734), a famous European urban designer and engineer. In the period of 17031716 he was the only architect working in St. Petersburg and the Head of City Development Office. It was D. Trezzini who designed the first general plan of the future city. Being a representative of the early Baroque in architecture he embodied his ideas in wonderful buildings which have decorated St. Petersburg. Among them, the Peter and Paul Cathedral in the Petropavlovskaia Fortress is the absolute masterpiece by Trezzini. The Fortress is the oldest building in St. Petersburg. The ceremony of its first stone-laying took place in 1703, May 20, and this date is considered St. Petersburg's birthday. There are several remarkable monuments of the Russian $18^{\text {th }}$ century architecture located on the Fortress grounds with the huge Peter and Paul Cathedral dominating over the whole city. The multi-tier bell-tower is crowned with a gilt 34 meter high spire with a flying angel at its top acting as a weather vane.

A lot of buildings constructed by Trezzini have remained up to now in St. Petersburg. They are Peter the Great's Summer Palace for (1710-1714) in Letniy Sad (Summer Garden), the Twelve Colleges building on the Neva

\footnotetext{
*Professor, The Leningrad State University named after A.S. Pushkin, Russia.
} 
embankment (1722-1734) (occupied by the State University). He also took part in the construction of Alexander Nevskiy Lavra - the Orthodox monastery and the Annunciatio Church, a big architectural complex "Gostiny Dvor" of the Vassilievskiy Island, and a lot of residences for St. Petersburg nobles. It was Trezzini who reconstructed Kronstadt Island and turned it into a fortress to guard St. Petersburg from the Swedes on the Gulf of Finland. It is important to note that European early Baroque characteristics acquired unique local features in St. Petersburg. They are seen in regular city planning, modest decoration, a harmonious combination of beautiful order elements with Baroque details. In some buildings decorative elements are emphasized by contrasting colors: red, pink, white.

An important part of this historical period: alongside the city construction music began to sound here. By Peter the Great's order, soldiersmusicians used to play music every day from 11 to $12 \mathrm{pm}$ from the highest points: the Peter and Paul Cathedral tower and the Chief Admiralty on the other Neva bank. Sounds of music swept over the Neva, blending with the sounds of stonemasons' hammers and carpenters' axes and creating a joyful rhythm of creation.

After Peter's death in 1724, Russian Empresses Anna Ioanovna, Elizaveta Petrovna, and Catherine the Great continued St. Petersburg construction, this process being the background for creating a new musical culture germs. Trezzini's architectural ideas were picked up by the famous Italian family of Rastrelli: the father Bartolomeo Carlo Rastrelli (1675-1744) and his son Bartolomeo Francesco Rastrelli (1700-1771). In their works, they fully embodied the magnificent Baroque style, which somewhat differed from Trezzini's but again had local characteristics. It effected the general composite plan of buildings when using traditional architectural orders Baroque details were emphasized, when pompous and splendor facades harmoniously matched with the city landscape and the environment. Some rationalism and modesty of the Petrine Baroque architectural forms were replaced by Rastrelli's rich and lush decorative elements.

None of the architects of that period possessed such amazing imagination, such a brilliant talent to create powerful architectural symphonies, where, in a full voice, sounded gold, blue, white, green, and red colors, the composition of columns, pediments, molding sculptures, light and shadow effects. Both Rastrelli were brilliant to use the whole expression means arsenal of the Baroque architectural style.

The most significant example of B.F. Rastrelli' work is Winter Palace (1754-1762), the beautiful building located in the city center on the Neva embankment. It is monumental, light and solemn construction. The architect wrote about it, "... this stone palace is being built for all-Russian glory." The eye cannot embrace the whole building from the embankment, it is possible to see its facade only from afar, e.g., from a boat or from Vasilievskiy Island 
arrow. The palace really dominated the city. Its size and height, unusual for those days, were emphasized by the whole decorative system. The palace is richly decorated with sculpture, which stands on the gable balustrade; the abundance of molded parts and complex rhythm of columns provide excellent exterior and interior of this building. It palace has 1,050 rooms and 1,945 windows that can give an impression about its size. The Winter Palace was the last monumental Baroque structure in St. Petersburg. The Russian emperors lived there until the Russian revolution, 1917. Now it is a famous Hermitage, the museum which is well-known all over the world. The Rastrelli family created also such remarkable edifices as Smolniy Convent, palace residences for Vorontsov's, Stroganov's, and Rasumovskiy's families, the Grand Peterhof Palace, Catherine's Palace in Tsarskoye Selo, Gatchina Palace, etc.

"The architectural symphony" of St. Petersburg was accompanied by the development of a new musical culture, which had various forms: chamber, instrumental, vocal, theater music. This period has brought the first Russian sonatas, romances, chamber works. The new secular culture of European sample has found its way to Russia. The vivid example is opera. This musical genre did not exist till the 18 century in Russia and was "imported" from Italy when St. Petersburg was being constructed. According to the $18^{\text {th }}$ century tradition the Opera House was a prestigious decoration of all European Imperial or Royal courts. Russian empresses Anna Ioannovna (1693-1740, reigning in 1730-1740), Elizaveta Petrovna (1709-1761, reigning in 1741-1761), and Catherine II the Great (1729-1796, reigning in 1762-1796) established favourable conditions for the bright opera flowering in Russia. A lot of brilliant Italian composers and performers were invited to the Russian empress court during the century. There were stars of the first magnitude among those who served as court composers, including Francesco Araja (1709-1775, lived in Russia in 1735-1760); Vincenzo Manfredini (1737-1799), served in Russia in 1758-1765 and 1798-1799); Balthazar Galuppi (1706-1785, served in Russia in 1765-1768); Tommaso Traetta (1727-1779, served in Russia in 1768-1776; Giovanni Paisiello (1740-1816, served in Russia in 1776-1784); Domenico Cimarosa (1749-1801, served in Russia in 1787-1791); Giuseppe Sarti (1729-1802, served in Russia in 1784-1802). They wrote opera and chamber music. Their music was heard permanently at the Hermitage theatre and in the Winter Palace halls. Having served the definite time under the contract, Italian composers were generously rewarded and returned home. Each of them undoubtedly made impact on the musical surroundings in St. Petersburg having taught composition, singing, performing instrumental music for Russian students who influenced the development of musical culture in Russia.

Francesco Araja (1709-1775) was one of the first Italian composers in Russia. He arrived to St. Petersburg in 1735 and had served there for 25 years. 
The opera birth in Russia is connected with his name. In 1736, his opera-seria "La Forza dell amore e dell' odio" (Force of Destiny and Hate) was represented for the first time giving the start of this genre. 14 operas by Araja were performed in St. Petersburg during 25 years of his living there, as well as a lot of cantatas, music festivals, and various chamber compositions designed for court festivities and entertainments. Especially for St. Petersburg court scene, Araja wrote a number of operas-seria, "Feigned Ninus, or Semiramis Recognized" (Il Finto Nino, o vero La Semiramide riconosciuta, 1737), "Artarkserks" (Artaserse, 1738), "Seleucus" (Seleuco, 1744), "Scipio" (Scipione, 1745), "Mithradates" (Mitridate, 1747), "Bellerophon" (Bellerofonte, 1750), "Alexander in India" (Alessandro nell'Indie, 1755), as well as an allegoric pastoral "Refuge of peace" (L'asilo della pace, 1748). Araya was the author of the first opera, "Cephalus and Procris" (Tsefal i Prokris, 1755) with Russian libretto by Alexander Sumarokov which was performed by Russian actors. Arija was the first composer who broke ancient traditions and involved the Court Chapel Choir for secular performances. The Central Music library in St. Petersburg (former the Imperial Theater Music Library) keeps the composer's original scores, intended for empresses Anna Ioannovna and Elizaveta Petrovna. They are in excellent condition, in spite of intervening centuries and the storms of history, and are used by today musicians

The composer's creative productivity was impressive, when almost annually magnificent Araja's opera performances took place at the imperial court, accompanied with a brilliant scenic design by Giuseppe Valeriani (1708-1762), an Italian theater artist. The high Baroque style dominated on the St. Petersburg stage. The scenery of majestic palaces, temples, and deep scenic vistas served the magnificent frame for Araja's operas, echoing the cities "architectural symphonies".

The Baroque stylistic foundations are known to take shape since the 16 century. There were no clear and steady borders dividing various cultural fields at the historic crossroads of that period. Mutual spiritual space made the essence of all European cultural processes when the art mirrored the spiritual life both of individuals and the society as a whole. Various forms of art - literature, poetry, theater, music, architecture, sculpture, painting, and engraving - featured the common stylistic direction, called the Baroque, which acquired its final mode in the middle of the $18^{\text {th }}$ century. Some distant art forms could influence each other. All of them expressed common stylistic features of the era. These phenomena can be observed in architecture and music of St. Petersburg in the $18^{\text {th }}$ century, when these two art fields got the lush blossom on the common cultural space of the young Russian capital.

Crossing all borders, the Italian opera conquered all of Europe, including Russia. The harmony of verse and music, the splendor of vocal bel canto, beautiful decorations and costumes, strong passions, and typal characters ensured long-term success for the opera-seria in the Russian court-aristocratic 
culture. Transplanted into the Russian land, the Italian music developed unique local features as well as the architecture created by the Italians. Having accepted the concept of the opera-seria as an important part of the festive court rituals Russia connected it with the reigning monarch. Archival documents show that the better part of the opera performances in St. Petersburg took place on the ceremonial days of reigning persons, e.g. birthdays, coronation and the throne accession anniversaries, etc. The operaseria corresponded these demands quite well, but it acquired some new features in Russia. The Italian opera-seria model was focused primarily on solo arias and recitative and regulated strictly the number of actors. There were usually a primo huomo (a neuter), a prima donna, and one or two minor characters.

The means of musical imagery of all arias (bravura, agitate, cantabile, etc.) were also strictly differentiated, each having its own vocabulary, tonality semantics, and solo instrument emblems. In the $18^{\text {th }}$ century, the opera-seria design remaining unchanged in Russia but a new typically Russian trait was introduced - the chorus as a collective actor. Living in Russia, Araya created the unique type of St. Petersburg grand opera, with the Courtiers-Capella chorus as a regular participant. Thanks to Araya operas the old culture of Russian ecclesiastical choral a'cappella began penetrating into the theater secular art. Russian classical composers' works accelerated this trend in the $19^{\text {th }}$ century ("Life for the Tsar" by M. Glinka, "Boris Godunov" by M. Mussorgsky, "The Maid of Pskov" N. Rimsky-Korsakov's, "Prince Igor" by A. Borodin). The opera-seria had been in demand in St. Petersburg until the end of the $18^{\text {th }}$ century. During this time, the Russian court scene had produced about 50 serious operas. With a few exceptions, they were all written by Italian composers, either directly in St. Petersburg, or before their coming to Russia, in this case the operas had undergone changes in accordance with the St. Petersburg style.

Alongside operas-seria, a new genre, opera-buffa (comic opera) was introduced by Italian maestros arriving in Saint Petersburg in the end of the $18^{\text {th }}$ century, e.g. Giovanni Paiziello and Domenico Cimarosa. Opera-buffa was enthusiastically received by a lot of music lovers. Thus, the musical theater with different stylistic trends has become an integral part of the cultural panorama in St. Petersburg.

Reflecting public interest, special theater buildings began to be built in St. Petersburg. The Hermitage Theatre (1783-1787, architecture by G. Quarenghi) and the Stone House (1777, architecture by A. Rinaldi) featured a different architectural style. The lush Baroque was replaced by the rigorous and balanced Classicism. The buildings constructed in St. Petersburg by the Italian architects Antonio Rinaldi (1740-1794), Giacomo Quarenghi (17441801), and Carlo Rossi (1775-1849) reflected the trends of various Classicism stages, e.g. the early Classicism (1760-1780), the middle one (1780-1790), and 
the high, or Russian Classicism (1800-1830). A galaxy of Russian architects was raised on Italian samples, Vasily Bazhenov (1737-1799), Alexander Voronikhin (1759-1814), Alexei Zakharov (1761-1811), Alexey Kokorin (17261772), Nikolai L'vov (1751-1803), Vladimir Stasov (1769-1848), and Ivan Starov (1745-1808) among them. By the end of the XVIII century, the combined efforts of Italian and Russian architects made St. Petersburg the beautiful city, its architecture sounded in unison with the environment and the music that filled the city.

Since the early $19^{\text {th }}$ century and by 1830 the construction of central squares (the Palace's, St. Isaac's, the General Staff's, the Admiralty's, the Theatre's, the Arts Square) have been completed in St. Petersburg making the beautiful ensemble. After the 1824 devastating floods, when the Neva had overflowed its banks and flooded the city centre, the river was "chained" with stone and granite embankments which became a detail of the city's architecture. It is very important in the city which has a lot of rivers, ducts, and channels, all together about 300 kilometers long. Pontoon bridges were built across the Neva in the $18^{\text {th }}$ century. With the time being, they were replaced with the stone, wood, and iron ones. There are 342 bridges in today St. Petersburg, each of them representing a unique architectural design. The two parts of some bridges are disconnected at night, opening the sea gates of the city. The picture of wrapped central span of the Palace bridge is one of St. Petersburg's symbols, as well as its White Nights in summer.

For over two centuries, the cultural city context had been formed including the architecture, music, literature, and poetry. In the $18^{\text {th }}$ century, St. Petersburg was often called "The Northern Venice." Gradually, St. Petersburg inhabitants and the guests began perceiving the city as a hypnotizing place, the city-theater, which was floating in space while retaining its architectural rigor pattern. None of the places, even Venice, possesses such a striking harmony of the architecture, the environment, and the musical incarnation. It is quite right to speak of St. Petersburg architecture as the "frozen music." The art of sounds, based on the numerical pattern, has the same deliberate architectonics which is characteristic for architectural masterpieces.

Whereas Italian architects and maestros can be considered the teachers for the Russians, Italy was a real source of inspiration for them, and the art connected these two countries. In 1773, Maxim Berezovsky made his debut with the opera "Demofont" in Livorno. In 1776 and 1778, Dmitry Bortniansky's operas "Creon," "Alcides," and "Quintus Fabius" were staged in Modena. In 1778, Peter Skokov's opera "Rinaldo" was staged at San Carlo theatre in Naples. The great Russian romantic Mikhail Glinka (1804-1856) had lived in Italy for three years studying bel canto, the Italian opera, and the contemporary symphony orchestra. His compositions were influenced by Italy: his chamber music pieces for strings were based on V. Bellini's "La 
Somnambular" and G. Donizetti's "Anna Bolena" motives. Glinka's "Fantasy Waltz," "Venetian Night" and others romances were also created under his impression of Italy. Peter Tchaikovsky (1840-1893) visited Italy many times. His trips to Florence were particularly productive. Nadezhda F. fon Meck, a well-known Russian patroness of art, used to rent a villa for Tchaikovsky in Florence. There, during the summer of 1878, Tchaikovsky composed his famous opera "The Queen of Spades," a string sextet "Memories of Florence," "Italian Capriccio" for the orchestra, some songs, and "Children's Album" for piano where Italian melodies - "Italian Song" and "Neapolitan Song" - were included which Tchaikovsky had heard in Italy.

The Italian musical theatre of the 18 century has formed the taste of the Russian audience and strongly influenced the Russian style of singing. A lot of grains of Italian culture, Italian language, and Italian melodies fell on the Russian soil and gave unique seedlings. One of these grains is "Russian bel canto."

The Italian bel canto culture was presented in the $18^{\text {th }}$ century in St. Petersburg by great singers of opera-seria A. Davia de Bernuchchi, K. Bonafini, K. Gabrielli, P. Mandini, Dzh. Gasparini, Matteo Buin, castrati Luini Bonetto, Lorenzo Salette, etc. In the $18^{\text {th }}$ century, A. Katalani, Dzh. Pasta, L. Damaro Cinta sang in St. Petersburg. There was a constant Italian theatre troupes working in St. Petersburg since 1843, it featured many outstanding singers - Pauline Viardot, Dzh. Rubini, A. Tamburini, etc. When the theater season stopped in spring the artists performed opera arias and duets in various concerts organically introducing Italian singing into the Russian culture context. Some of the singers gave singing lessons to Russian students, grand dukes and princesses, numerous fans, and actors from private theatres of Sheremetev's, Elagin's, Yusupov's, Vorontsov's families among them. Italian composers taught at St. Petersburg educational institutions as well, in Smolniy Institute, the Theatre School, Fine Arts Academy, where the curriculum included "learning the Italian way of singing."

Let us highlight some circumstances that demonstrate the closeness of the two cultures, Russian and Italian. There is a certain similarity in the phonetic nature of Italian and Russian languages, where the abundance of vowels facilitates melodious singing on a broad and long breath. Italian and Russian folk songs are similar due to the same reason. Vocalization ability and holding long tones and phrases in one breath can be observed both in Russian folk singing and in Italian folk melodies.

However, the bel canto professional tradition makes some special demands for the singers. The virtuoso singing technique is characterized by the smoothness of the sound to sound transition, relaxed, beautiful, and rich sound color, voice evenness in all registers, and the easy sound line. It requires the perfect possession of the voice, its tapering, special singing 
breath, emotionally saturated and beautiful singing tone, and performing expression. A singer's voice is his/her main tool in bel canto.

The Russian vocal school, though developing its own way, used the Italian singing principles. M. Glinka, A. Varlamov, A. Dargomyzhsky and other Russian composers of the first half of the $19^{\text {th }}$ century have formed a new aesthetic of Russian vocal singing in their romances, voice exercises, and their "schools" taking into account Italian achievements. Glinka who is considered the founder of the Russian singing school, proved the voice natural development up and down in his "concentric method." Varlamov, having used the best European theoretical works in his "School of Singing," worked out an original method and pointed that a state of mind effecting directly on the vocal organs is the base of any vocal. That is why the singing is the language of the heart and passions. He was supported by A. Dargomyzhsky, the author of the "Rusalka" opera and a large number of songs. He was also known as a vocal teacher in St. Petersburg who wanted his students "voices to express the truth."

The opening of the first Russian conservatories with vocal departments, in St. Petersburg (1862) and Moscow (1864), was of great importance for the vocal art development. Again, we see the Italian impact here. Everardi Camillo (1825-1899), the famous Italian opera singer was the founder of the St. Petersburg school of vocal. He started teaching at St. Petersburg Conservatory in 1870, worked at Kiev and Moscow conservatories as well. He served in Russia until his death in 1899. There were Fyodor Chaliapin's teacher Dmitri Usatov, Igor Stravinsky's father Fyodor Stravinsky, wonderful singers M.A. Deysha-Sionitskaya, Jokim Tartakov, Stanislav Gabel (18491924) among Everardi's students. The later continued their teacher's work at St. Petersburg Conservatory. The number of Everardi's students was incredibly large, his pedagogical "grandchildren" transfer the great master's lessons to young Russian singers.

\section{Conclusion}

Thus, summing up, we can say that the long history of Russian-Italian relations made a strong impact on Russian culture, especially in St. Petersburg where two kinds of art - music and architecture - evolved together complementing and influencing each other. Thanks to Italian masters, the architects and composers, the unique cultural atmosphere was being established in the new Russian capital during the $18^{\text {th }}-19^{\text {th }}$ centuries. The Italian architects created the "architectural symphony" of St. Petersburg, with quite a number of beautiful palaces, whereas the Italian composers and singers brought the European secular culture to Russia. Operas, opera-seria 
and buffa, as the new musical genres, Italian singing lessons, and conservatories - these are the examples of the Italians' participation in the development of Russian culture.

When the music of bygone centuries had given way to new musical trends the "architectural symphony" continued sounding emphatically and meaningfully in the city. The symbolic aphorism "architecture is frozen music" corresponds to this situation quite well. The Italian composers' contribution has not been forgotten as well. Libraries and archives of St. Petersburg are keeping their priceless scores which are often used by today musicians.

The $18^{\text {th }}$ century Italian musical theatre formed the taste of the Russian audience and strongly influenced the Russian style of singing. The certain similarity in the phonetic nature of Italian and Russian languages promoted the success of the Italian operas in Russia and permitted the Russian singers to acquire the peculiarities of the Italian bel canto. The Italians gave birth to Russian bel canto, the unique phenomenon, nurtured on the basis of the Russian culture with the help of the Italians. Outstanding Russian artists Fiodor Shalyapin, Antonina Nezhdanova, Leonid Sobinov, Irina Arkhipova, Elena Obraztsova, Vladimir Atlantov, Galina Vishnevskaya, etc. were perfect in possessing the bel canto art remaining deeply Russian singers. The modern Italian bel canto continues to be the standard of the classical singing, beautiful in tones, cantilena, and long breath. The art of the best world singers - Joan Sutherland, Maria Callas, Birgit Nilsson, Boris Christov, Nicolai Gyaurov, Luciano Pavarotti, Placido Domingo. There is a whole galaxy of Russian singers in today's vocal Olympus, they are Anna Netrebko, Dmitri Hvorostovsky, Sergei Leiferkus, Dinara Alieva, Hibla Gertsmava, Dimitri Korczak, Maria Gulegina. All of them keep worthily the position of Russian bel canto.

\section{Bibliography}

Barsova L. G. Из истории петербургской вокальной школы (From the history of the Petersburg's vocal school). St.-Petersburg, 1999.

Музыкальный Петербург. XVIII век (The Musical Petersburg. XVIII century). Encyclopedic dictionary. Vol. I - III. St. Petersburg. 1996; 1998; 1999.

Памятники архитектуры Ленинграда. (The architectural monuments of Leningrad). Leningrad, 1975.

Perlov Е. Р. История вокальной педагогики. (The history of vocal pedagogics). St.-Petersburg, 2007. 
Petrushanskaya Е. М. Михаил Глинка и Италия (Mikhail Glinka and Italy). Moscow, 2009.

Rytsareva M. G. Композитор Д.Бортнянский. Жизнь и творчество (Composer Dmitry Bortniansky. His life and work.). Leningrad, 1979.

Rytsareva M. G. Композитор М.С. Березовский (Composer M.S. Berezovsky). Leningrad, 1983.

Samsonova T. Р. Музыкальное образование в учебных заведениях СанктПетербурга XVIII века. (The music education in the schools of St. Petersburg in the XVIII century). St. Petersburg, 2006.

Samsonova T. Р. Музыкальная культура Санкт-Петербурга XVIII - XX веков (Musical Culture of St. Petersburg of XVIII - XX centuries). St. Petersburg, 2013.

Shtehlin Y. Известия о музыке в России (The news of the music in Russia). Moscow, 1935. 